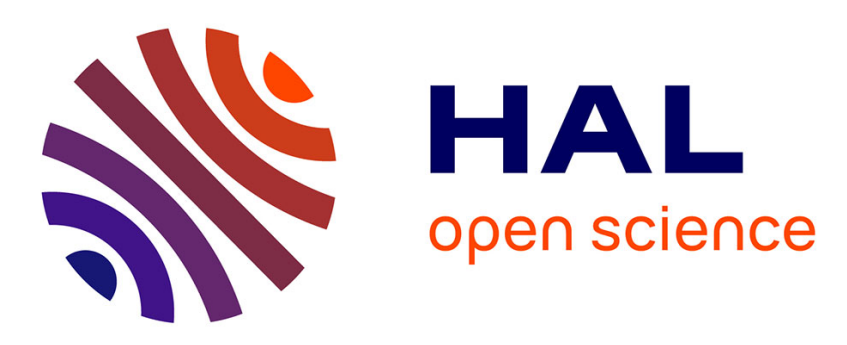

\title{
Thermal Radiative Properties of Bardarbunga Basalts: Importance of Emissivity in Magma Rheology and Volcanic Hazard.
}

Jonas Biren, Lionel Cosson, Leire del Campo, Cécile Genevois, Emmanuel Veron, Sandra Ory, Hao Li, Joan Andújar, Aneta Slodczyk

\section{To cite this version:}

Jonas Biren, Lionel Cosson, Leire del Campo, Cécile Genevois, Emmanuel Veron, et al.. Thermal Radiative Properties of Bardarbunga Basalts: Importance of Emissivity in Magma Rheology and Volcanic Hazard.. AGU 2021 Fall Meeting, Dec 2021, Online, France. 10.1002/essoar.10509907.1. insu-03559137

\section{HAL Id: insu-03559137 \\ https://hal-insu.archives-ouvertes.fr/insu-03559137}

Submitted on 6 Feb 2022

HAL is a multi-disciplinary open access archive for the deposit and dissemination of scientific research documents, whether they are published or not. The documents may come from teaching and research institutions in France or abroad, or from public or private research centers.
L'archive ouverte pluridisciplinaire HAL, est destinée au dépôt et à la diffusion de documents scientifiques de niveau recherche, publiés ou non, émanant des établissements d'enseignement et de recherche français ou étrangers, des laboratoires publics ou privés.

\section{(c)(1)}

Distributed under a Creative Commons Attribution| 4.0 International License 


\section{Thermal Radiative Properties of Bardaybung
Basalits: Importance of Emissivity in Wagma Bhoology and Volcanic larard}

Jonas Biren ${ }^{1 *}$, Aneta Slodczyk ${ }^{1,2}$, Lionel Cosson ${ }^{2}$, Leire del Campo ${ }^{2}$, Cécile Genevois ${ }^{2}$, Emmanuel Veron ${ }^{2}$, Sandra Ory ${ }^{2}, \mathrm{Hao} \mathrm{Li}^{1}$, Joan Andújar ${ }^{1}$

${ }^{1}$ CNRS-Université d'Orléans, ISTO, BRGM, UMR 7327, F45071, Orléans, France.

${ }^{2}$ CNRS-Université d'Orléans, CEMHTI, UPR 3079, F-45071, Orléans, France.

V23A-04 - Properties of magmas- 14 December 2021 


\section{PhD student at ISTO, University of Orléans - Orléans, France}

- Institut des Sciences de la Terre d'Orléans

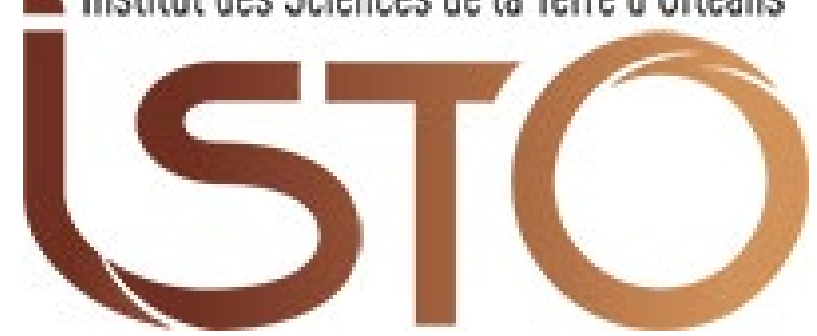

Cemhti
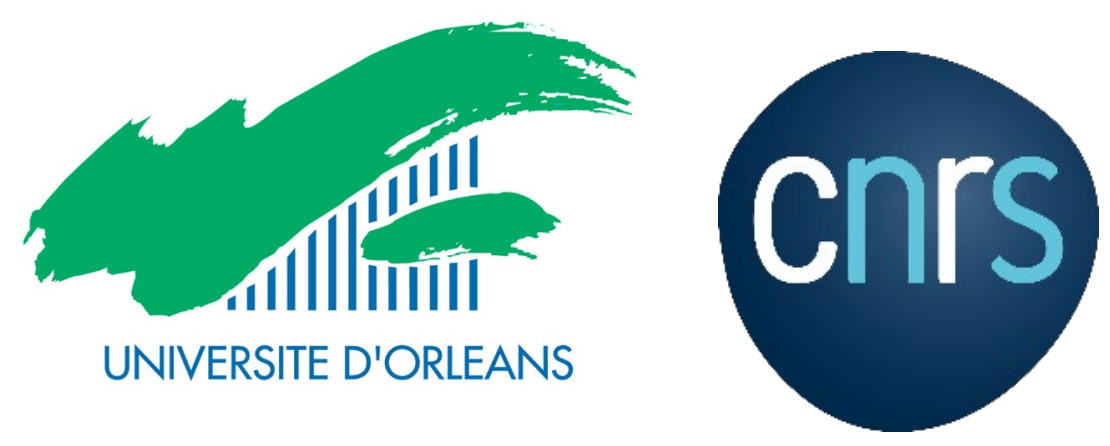

SCIENCE is SOCIETY 


\section{TEMPERATURE - KEY PARAMETER TO UNDERSTAND LAVA FLOW RHEOLOGY}

Lava flow T retrieved by remote sensing (RS) depends on spectral emissivity $(\varepsilon)$.

$\varepsilon$ poorly known: considered constant or retrieved at RT

Only few studies of $\varepsilon$ at relevant magmatic conditions:

- Limited $\mathrm{T}$ range $\left(<\mathrm{T}_{\mathrm{g}}\right)$ / spectral range (TIR)/ composition (synthetic)

High Temperature and broad spectral range $\varepsilon$ data are necessary!

In situ measurements of $\varepsilon$ with FTIR spectrometers up to $1800 \mathrm{~K}$, in SWIR-MIR-TIR

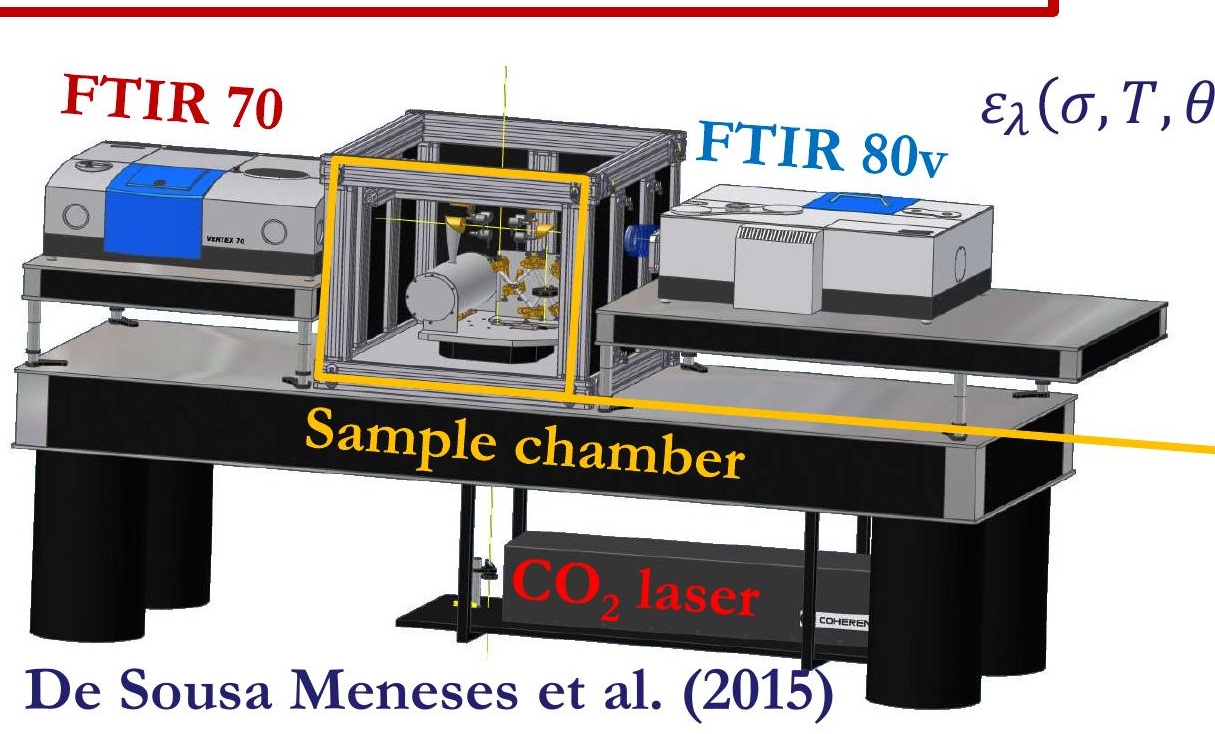

T?
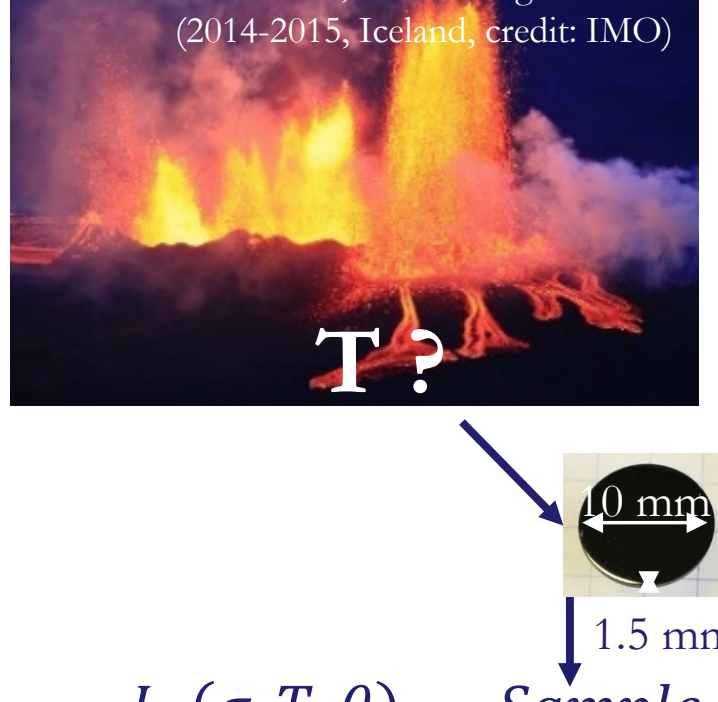
$\varepsilon_{\lambda}(\sigma, T, \theta)=\frac{L_{\lambda}(\sigma, T, \theta)}{L_{\lambda}^{0}(\sigma, T, \theta)}=\frac{\text { Sample }}{B B}$ 


\section{ACH FALL MEETING}

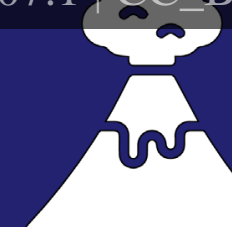

\section{SPECTRAL EMISSIVITY BEHAVIOR OF BASALT WITH GRYSTALS}
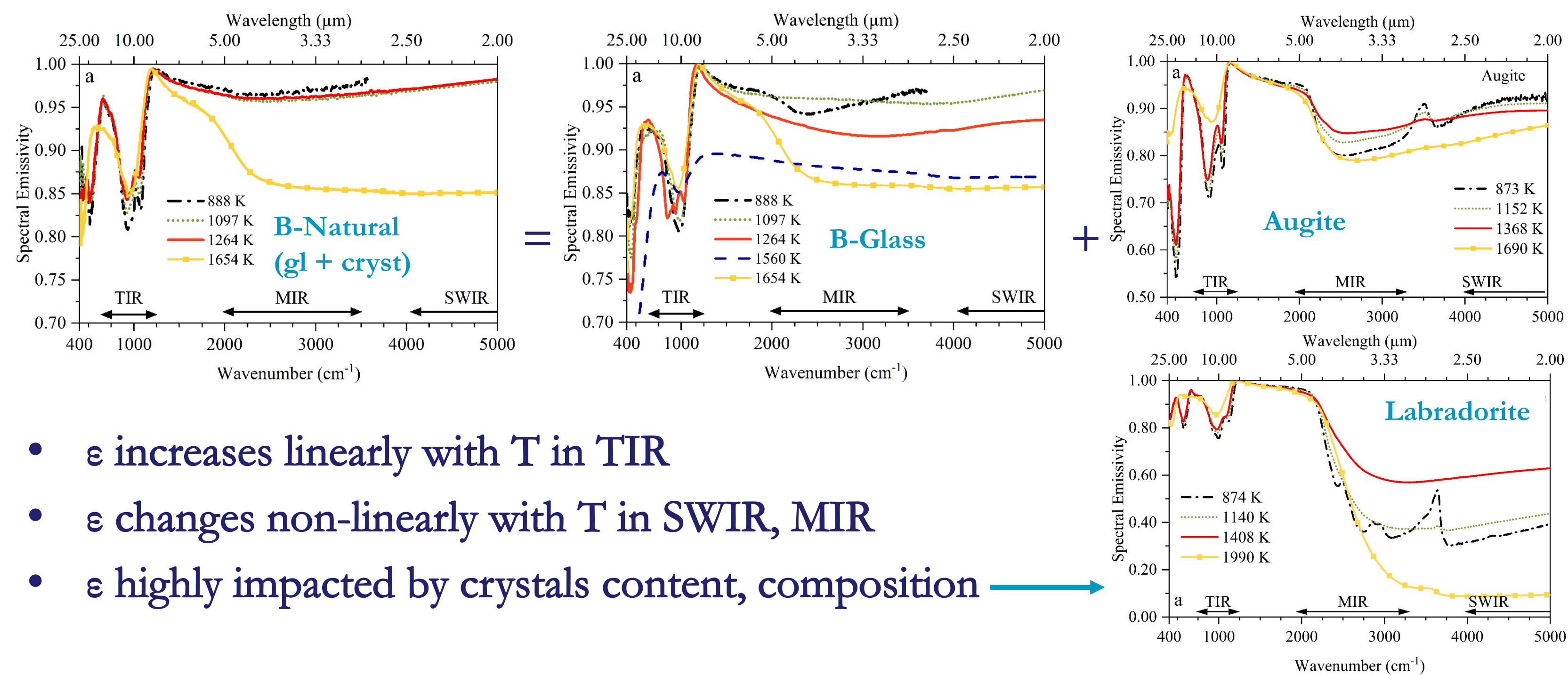

- $\varepsilon$ increases linearly with T in TIR

- $\varepsilon$ changes non-linearly with T in SWIR, MIR

- $\varepsilon$ highly impacted by crystals content, composition 
$\varepsilon$ behavior is highly complex

- depends on $\lambda$, T, composition, and crystal content

Better constrain on surface radiance

- Refine $\mathrm{T}$ by $\sim 50$ degrees with RS

More appropriate rheological evolution

- lava flow behavior: from liquidus to subsolidus

Reduce uncertainty in lava flow modeling

- improve hazard assessment

Poster Hall D-F: Improving field lava flow temperatures with lab-based spectral emissivities for the 2014-2015 Holuhraun eruption, J. Biren et al., NH25A-0528, Advances in modelling for natural hazards and risk. 16:00-18:00
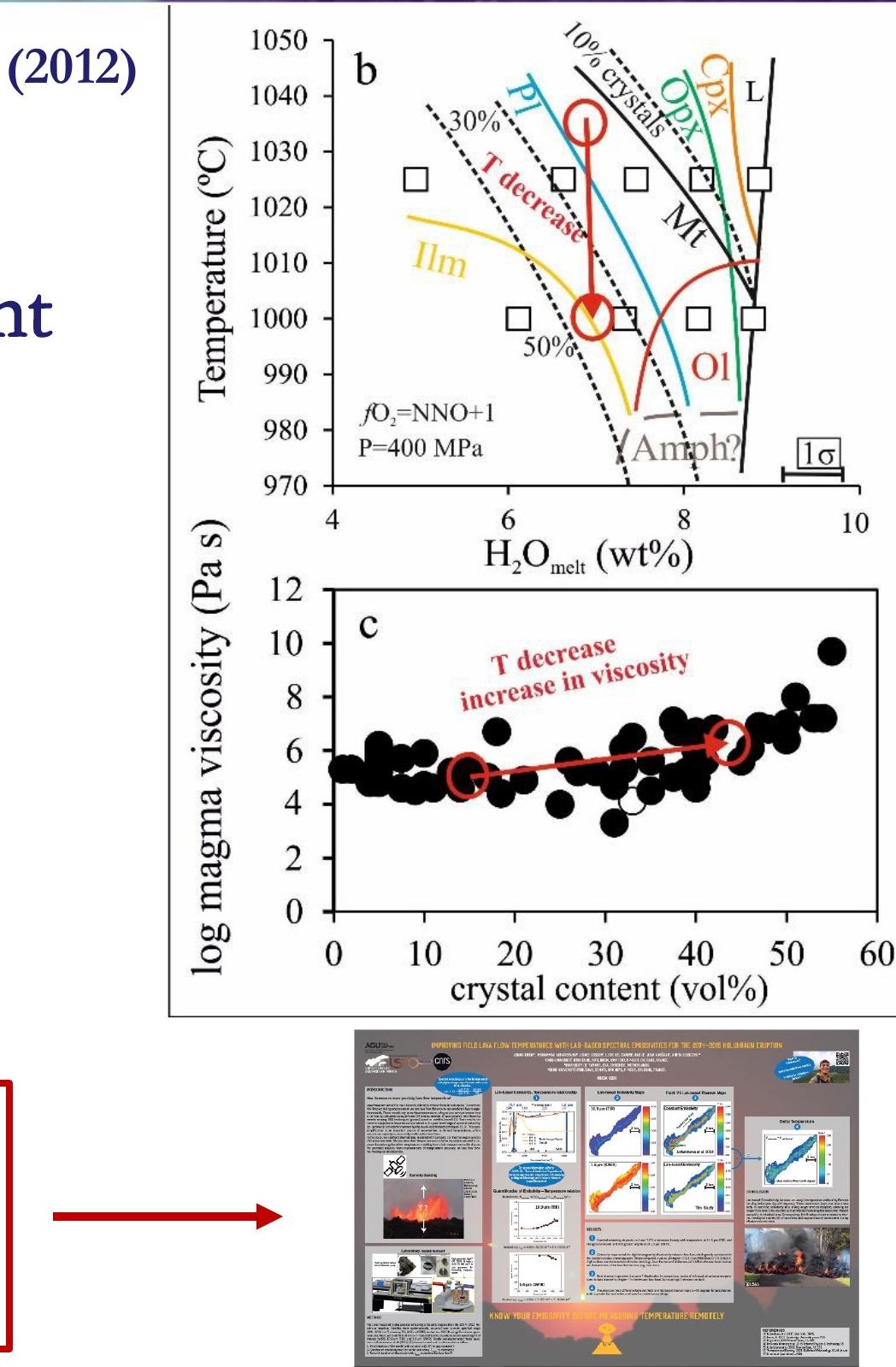


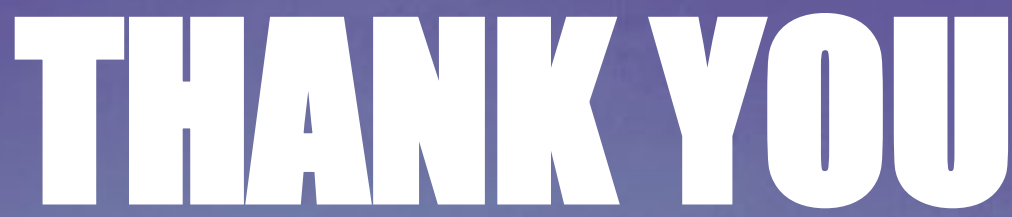

Looking for a postuloc follow? jonas.hiren@enis-orloans.ir

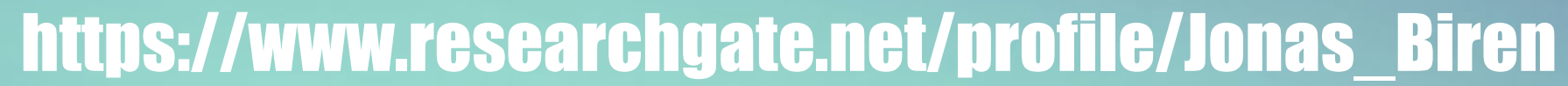

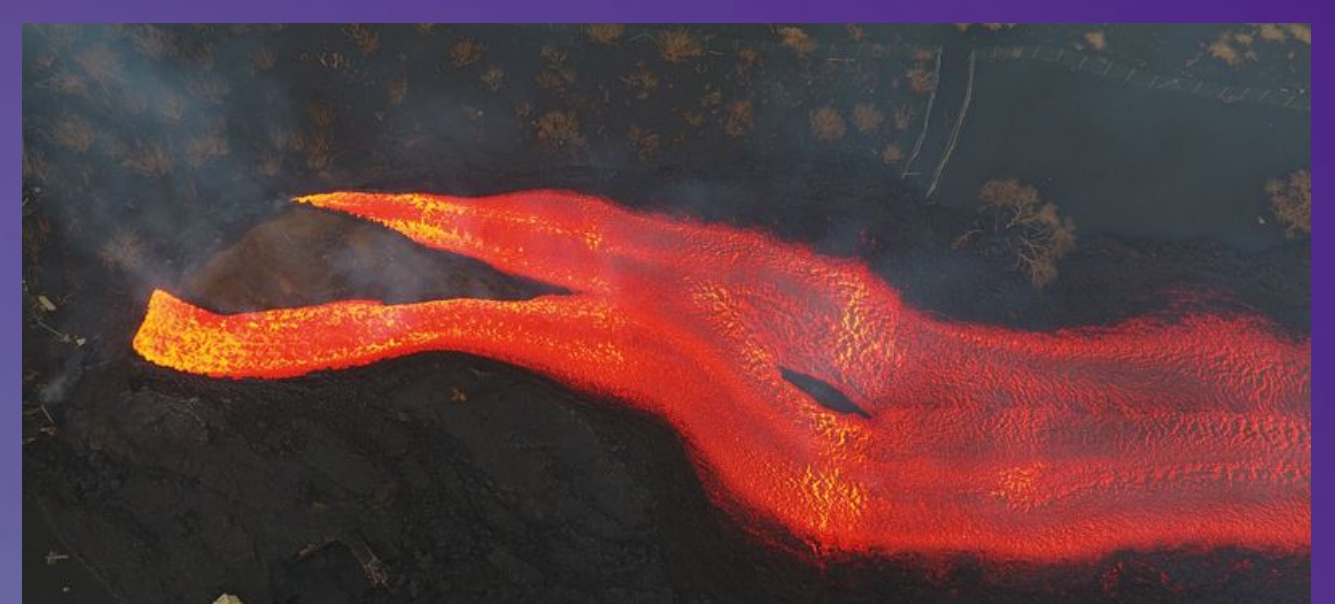

La Palma eruption (2021), credit: IGME

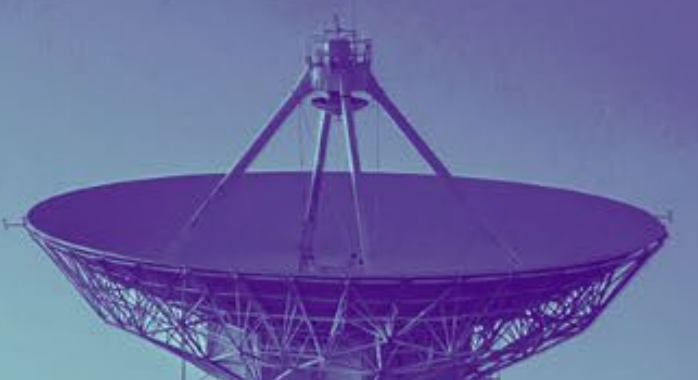

SCIENCE is SOCIETY 